\title{
Affinity Spaces and Ecologies of Practice: Digital Composing Processes of Pre-service English Teachers
}

\author{
PATRICK HOWARD \\ Cape Breton University
}

\begin{abstract}
English educators are responsible for preparing pre-service and in-service teachers to consider the ways in which people engage in meaning making by using a variety of representation, interpretive and communication systems. Today new technologies are radically changing the types of texts people create and interpret even as they are influencing the social, political and cultural contexts in which texts are shared. The concept of ecology helps us to re-think the traditional linear process of text creation and informs an approach to teaching new media in interesting ways. This research project was designed to immerse pre-service English education students in the creation of multimodal, multimedia texts as part of a digital composing workshop. For the purposes of this paper, three student experiences were drawn from a group of twelve pre-service English education students participating in the project. Despite the ever present barriers to integrating afterschool (Prensky, 2010) literacy practices into traditional schools, literacy teachers are challenged to ensure what they are teaching has the important element of life validity (Mills, 2010) and reflects the evolving socio cultural literacy practices of contemporary society. In turn, English educators must provide authentic, engaging opportunities for pre-service literacy teachers to learn about and through multimedia, multimodal digital technologies.
\end{abstract}

\section{Introduction}

James was noticeably uncomfortable. The anxiety was barely masked in his voice. His English methods instructor had just explained that, as part of the semester course work, the pre-service teachers would create a multimodal digital text to share with the class at the end of the term. Another student, Anna, was visibly engaged by the announcement. She was excited by the prospect. The other students, on hearing the details of the assignment, shared a range of reactions somewhere between those of James and Anna.

English educators are responsible for preparing pre-service and in-service teachers to consider the ways in which people engage in meaning making by using a variety of representation, interpretive and communication systems. Literacy educators also encourage teachers to consider the relationships that exist between readers, writers, texts, contexts and the situations in which texts, in their many forms, are written and read (Knobel \& Lankshear, 2007; Kress, 2003). Today, new technologies are radically changing the types of texts people create and interpret even as they are influencing the 
social, political and cultural contexts in which the texts are shared (Jewitt \& Kress, 2003). In order to provide opportunities for K-12 students in Canadian schools to engage in composing processes that make use of multimodal and multimedia digital technologies, pre-service literacy teachers need to understand the values, possibilities, pedagogies and constraints of multimodal literacies and multimedia technologies (Doering, Beach \& O'Brien, 2007; National Council Teachers of English, 2005). A growing number of researchers are exploring the media practices and emerging digital literacies of children and youth (Barrell \& Hammett, 2002; Howard, 1987; Knobel \& Lankshear, 2007; Mills, 2010), yet few studies have inquired into the composing processes of pre-service literacy teachers and the pedagogical possibilities to emerge from immersing prospective literacy teachers in constructing multimodal, multimedia texts (Buck, 2012; Miller, 2007; Robertson, Hughes \& Smith, 2012).

Composition theorists have long advocated the immersion of student writers in the work of writing facilitated by daily opportunities to create personally relevant, meaningful texts in a supportive community of writers. The approach has been called the social turn in writing pedagogy and it has dominated instructional approaches to writing since the $70 \mathrm{~s}$ and $80 \mathrm{~s}$. The workshop approach and its variants have been central to writing pedagogy for nearly three decades (Atwell, 1993; Calkins, 1994; Graves, 1983; Kittle, 2008; Murray, 1982; Romano, 1987; Soven, 1999). This research project was designed to immerse pre-service English education students in the creation of multimodal, multimedia texts (LaMonde \& Rogers, 2007). It was undertaken as part of a digital composing workshop designed to facilitate the integration of multimedia technology in the composing process with the goal of fostering creative ways of connecting different forms of digital expression. Many scholars in New Literacies research argue simply using digital media technologies is not enough; critically understanding how these technologies enable New Literacies and meaningful communication should become a core curricular and pedagogical function of English education (Cervetti, Damico \& Pearson, 2006; Cope \& Kazlantis, 2000). New Literacies involve more than simple technical or digital concerns; it is possible to use new technologies to simply replicate conventional, longstanding literacy practices. The significance of new digital technologies has to do with how it enables people to build and participate in literacy practices that involve different kinds of values, sensibilities, norms and procedures from those that characterize conventional literacies. It is the values and pedagogies of collaboration and participation, the harnessing of collective intelligence, the building of relationships, and the de-centering of authorship that are characteristic of New Literacies.

Others criticize the New Literacies argument contending that extending linguistic grammars to also include other modes (audio, visual, spatial, gestural) overwhelms the discipline (Burn \& Nixon, 2005). Mills, who advocates for the inclusion of New Literacies, succinctly captures these dissenting concerns saying their arguments are related to the generation of "an overwhelming range of new content and genres for English teaching and ... tools of semiotic analysis that are not yet developed" (2010, p. 251). This being said, there is a shared recognition that reading and writing practices using words in paper-based text formats are necessary, but not sufficient, for communicating across multiple platforms of meaning-making in contemporary society. 
However, to date, there is no clear consensus on the role of multiple literacies in K-12 classrooms. Nevertheless, it is becoming increasingly clear that to allow students to more fully engage in the digital literacies they are immersed in out of school, pre-service teachers of English language arts should be prepared to facilitate a more textured and complex approach to the composing process that is not a linear process, but reflexive, multimodal, interactive and multidimensional reflecting the New Literacies as new practices. As future teachers of writing, pre-service education students who were engaged in creating multimodal, multimedia texts will be better prepared to facilitate the design and production of multimodal, multimedia texts. This will allow the young students they will one day teach to draw on both social and genre knowledge to move across digital modes.

\section{New Literacies and Ecologies of Practice}

Literacy studies shifted focus fundamentally in the 1970s in part due to a revival of the work of Vygotsky (1986) who saw language as influenced and constituted by social relations, hence the 'social turn'. Research on literacy conducted across a range of disciplines including social linguistics, anthropology, and cultural studies inquired into how language functions as a tool for shaping, controlling and interacting with one's social and physical environment (Mills, 2010). This approach is what Gee (1990) terms New Literacy Studies as it seeks to understand literacy across the full spectrum of contexts including; cognitive, social, cultural, moral and historical (Lankshear \& Knobel, 2011). A recent and significant addition to this spectrum has been dubbed the "digital turn" (Mills, 2010, p. 246) in that new literacy practices in digital environments across a myriad of cultural contexts have risen in prominence. Research on New Literacies is increasingly reflecting the changing emphasis from research in print-based reading and writing practices to include new textual practices mediated by digital technologies. The 'social turn' of the late 70 s and early 80 s is subsumed by the 'digital turn' of the new millennium. These technological literacies (Lankshear, 1997), referred to by others as digital literacies (Dobson \& Willinsky, 2009), are defined as social practices mediated by way of computers and continuously evolving with the appearance of ever more sophisticated mobile, hand held devices. Dobson and Willinsky (2009) argue engaging in meaning making and communication in the digital age will entail becoming well versed in different semiotic modes - visual, textual, and verbal. Digital literacy and text creation requires visual literacy and the concepts and skills associated with images and representation.

As we move into the second decade of the new century, the metaphor of ecology (Cooper, 1986) and its relation to digital media environments becomes vital and significant. Brooke (2009) argues for increased attention to "ecologies of practice" that open up inquiries into dynamic intersections between mediated literacies practices as hybridized social text creation in digital spaces. This concept of ecology contrasts with continued emphasis on static text and our reliance on linear, transmissive, solitary, printbased text creation. To continue to emphasize transmissive, linear, process pedagogies puts us not only out of sync with our students and the larger culture, but represents a missed opportunity to understand what is happening in the space between the text creator and the digital interface which is a place of dynamic interplay and creativity. 
In the research reported here, Brooke (2009) is especially important. He provides a theoretical framework by which to better understand post-process writing pedagogy that broadens notions of writing to include multimedia, multi modal digital texts. Interestingly, and somewhat ironically, Brooke's theory returns to classical rhetoric and the five rhetorical canons (invention, arrangement, style, memory and delivery). He employs the lens of ecological systems thinking to re-interpret composition theory and "to re-think notions of rhetorical effectiveness" (Brooke, 2009, p. 28). Brooke argues writing process theory that currently dominates writing pedagogy has evolved directly from the traditional canons:

One must come up with ideas, put them in a particular order, figure out how to express them, memorize the text that results and finally deliver it. Because the latter two steps are not relevant to the composition of a written text, it follows the corresponding canons have become obsolete. (Brooke, 2009, p. 30)

By using the metaphor of ecology Brooke (2009) breathes new life into the traditional canons by arguing that when viewed ecologically the canons "provide a much broader scope, particularly for our inquiry into new media, than can process theory" (p. 36). Process theory emphasizes the production of static textual objects. As we turn to multimedia and digital interfaces, we require a "model capable of taking account of not simply the process leading up to a release, but the activity that follows as well" (p. 38). Brooke suggests the canons represent an "ecology of practices" that contains a discursive, recursive, dynamic interplay of "codes, practices and culture" (emphasis added, p. 47). This "trivium" as Brooke calls it, evoking the classical rhetorician's Latin, “... is valuable because it may help us understand that the most important changes wrought with and by new media are changes in our ecologies of practice (emphasis in original, p. 47). Ecologically, practice includes all of the "available means" and our decisions regarding which of them to pursue. Brooke posits, "in the case of interfaces, this ecology also includes not only those practices involved in the production of the interface, but those made possible by it" (p. 49). In the dynamism of an ecological system, it is important to realize those practices that may be unintended or unanticipated - users may take up and re-purpose interfaces “expanding their ecology of practice beyond a designer's intention mediated through interpersonal relationships and local discourse communities, to regional, national and even global cultures" (p. 49).

Using the metaphor of ecology allows for an expanded concept of "writing." Returning to the canons of classical rhetoric, as understood through the lens of ecology, a complex system of people, sites, practices and objects emerges to create an ecology of practice within which the canons operate. The printed text is but one site of practice and analysis. An ecological view of composition includes a multiplicity of practices that includes new media with its own codes, practices and culture. Seen through an ecological lens, composition practices are understood more broadly as an on-going, ever evolving system shaped by individual users, technologies and the intersection of dynamic contexts. 


\section{Writing Pedagogy in a Digitally Mediated Space}

New and innovative technology has created changes and challenges in education while suggesting new ways of teaching and learning, including how literacy educators teach writing (Swenson, Rozema, Young, McGrail \& Whitin, 2006). Traditionally, writing and writing methodologies regard computer technologies as tools useful for word processing capability (Soven, 1999). Popular and influential writing methodology texts published in the last decade view the relationship between computers and writing for, primarily, their word processing capability whereby student writers "mess around more with text-saving, rearranging, adding, deleting" (Atwell, 1993, p. 102). The widespread introduction of word processing did not challenge our notions of textuality and literacy because the technology was seen as directly related to preparing documents for printing on paper (Dobson \& Willinsky, 2009). This research project is situated within a perspective that broadens notions of writing to include multimodal, digital literacies as ways of communicating across a variety of print and non-print media and genre. In an increasingly complex multimedia world, some would argue that schools continue to privilege "pencil and paper" print literacy. It has been argued, that teacher education has played a conservative role, in the sense of conserving or perpetuating the practices of the past (Cervetti, Damico \& Pearson, 2006; Miller, 2007). Also, it has been pointed out that pre-service English teachers' university preparation in traditional English degree programs is unsuited to the knowledge and skills necessary to teach students increasingly immersed in a range of digital genres and semiotic codes (Barrell \& Hammett, 2000). The field has also had its share of overt criticism of technology and the role it plays in the writing classroom (Cuban, 2001; Greenleaf, 1992; Owston, 1992). Criticisms have also been leveled at multimedia communications and the erosion of print-based literacy (Rosen, Chang, Erwin, Carrier \& Cheever, 2010). Others argue the competence with new technologies demonstrated by adolescents is often "inappropriately re-construed as incompetence with print-based literacies" (Dobson \& Willinsky, 2009, p. 295). Despite the recent proliferation in Information Communication Technologies (ICTs) by which students both read and compose, understand and produce multimodal digital texts, the general focus in English education is on technology as a tool rather than using ICTs to open spaces for socially situated literacy practices (Pahl \& Rowsell, 2005). Many in the field still accept a conceptual separation of literacy from technology, despite the theory connecting them (Grabhill \& Hicks, 2005). Dobson and Willinsky (2009) also point to the paradox of digital literacy indicating it constitutes an entirely new medium for reading and writing while extending and continuing a print culture.

Key theoretical assumptions guided this research project. First, English educators are struggling with "a discipline in metamorphosis" (Barrell, Hammett, Mayher, \& Pradl, 2004, p. 2). Secondly, it is important to bridge the binary between literacy and English language arts on one side and technology as a "tool" on the other side. Myers' (2006) definition of New Literacies erases these divisions by describing them as "evolving social practices that coalesce new digital tools along with old symbolic tools to achieve key motivating purposes for engagement in the literacy practices" (p. 62). 


\section{Methods}

Two key objectives of this research project were: 1) to understand the composing processes required by teachers to help secondary school students learn to employ interactive digital technologies to create effective text and 2) to inquire into the experiences, attitudes and beliefs of pre-service English education students as they engage with multimodal, digital text creation.

Porter (2007) believes research on digital composing cannot rely on the same methodologies used to study print-based composing simply transported to a digital environment. An eclectic adopting of methodologies allows for the capturing of local environments and the unique circumstances of the writing environment. This research project employed qualitative research methods to elicit the perceptions, attitudes, beliefs and experiences of pre-service literacy teachers arising out of their immersion in composing multimodal, multimedia texts.

\section{Participant Recruitment}

Voluntary participation was sought from pre-service literacy education teachers enrolled in the after degree teacher education program in a small, primarily undergraduate university in eastern Canada. All students participated in the project, however only those who provided informed consent were included in this research. Specifically, pre-service education students used multimedia technologies to compose digital texts. The tasks involved both understanding and producing multimodal digital texts. Using an adaptation of Atwell's (1993) workshop approach to writing pedagogy, pre-service teachers devised a list of "writing territories" (Atwell, 1993, p. 120); that is, personal lists of subjects to explore through composition. One of these topics was to be explored through multimedia, multimodal digital technology. Within the classroom space, rather than simply creating multimodal texts for the teacher/researcher, participants were invited to seek out and participate in social, on-line communities or "affinity spaces" (Gee, 2004). In these participatory on-line spaces, participant contributions are, for the most part, valued by other members in a supportive community (Jenkins, 2006). The teacher/researcher acted as participant observer. In participant observation, a researcher's discipline-based interests and commitments shape which events he or she considers are important and relevant to the research inquiry. According to Ambert, Adler, Adler and Detzner (1995), the four stages that characterize most participant observation research studies are: establishing rapport or getting to know the people, immersing oneself in the field, recording data and observations, and consolidating the information gathered. While the researcher acted as teacher, participants provided consent and indicated they understood they could withdraw without prejudice or penalty from the project at any time and not have their materials included in the research. Preservice teachers received support and instruction in using the technologies and in designing digital texts using semiotic modes including visual and graphic design principles through the use of icons, images, buttons, print and interfaces carefully chosen for contextual suitability. 


\section{Data Collection}

The inquiry relied on four primary sources of data: digital journal and diary records of participants' direct experience of the composing processes, face-to-face interviews, questionnaires and experiential material derived from close ethnographic and phenomenological observations. Thematic analysis of the journal entries, interviews, questionnaires and observations was conducted for phenomenological insights of pedagogical value (van Manen, 1997). As part of the data collection, classroom activities were designed to stimulate student reflection and were based on the belief that reflection on experience potentially results in deeper awareness of taken for granted assumptions as it interrupts norms and routines. Detailed conversational interviews (van Manen, 1997) and opportunities for reflection took place before, during and after each digital composing project to determine prior knowledge, attitudes, and potential barriers to participation. Throughout the project, the researcher and research assistants acted as participant observers and collected data using observation notes and the audio recording of sessions. During the digital composing sessions, selected participants were interviewed at key points to gain a more in-depth perspective of noteworthy literacy events identified through observation.

The analysis was qualitative and interpretive. Research data consisted of: detailed field notes; transcribed interviews with participants; the digital texts created by participants; the digital diaries and discussions of participants; and audio recordings of selected learning/authoring sessions. For the purposes of this paper three English preservice teachers' (James, Anna and Kyle) experiences with creating digital media texts serve as the focus for better understanding teachers' engagements with newly accessible multi modal literacy practice. Each example represents a unique experience from which we can draw meaning. All names are pseudonyms except for Kyle. Kyle waived the choice to use a pseudonym and consented to reveal his identity. He had posted his digital text to YouTube and wanted to make it publicly available in the interest of the research project and for his own creative purposes. The visuals included in the paper point to the larger purposes in the creation of the digital texts; each text illustrates a range of literacy skills required to create the text including multimodal literacy strategies, critical literacy strategies and media literacy strategies.

\section{James}

I described briefly at the beginning of the paper the anxiety James exhibited on hearing one of the pieces to be included in the portfolio for an English language arts course was to be a multimedia digital text. He described his initial reaction later as "having a panic attack." Miller (2007) also described similar responses as "teachers struggled with reservations and with unfamiliarity and lack of proficiency" (p. 69). James' literacy life journey (see Bainbridge, Malicky \& Heydon, 2009), revealed through conversational interviews, provided insight into his initial reaction and the potential barriers to teachers' becoming confident, proficient models of multimedia use in the classroom. James, a 40-something former ESL teacher, was struggling to expand his repertoire to include New Literacies. This struggle was deeply related to his lived experience and personal history. "The extent of my computer literacy was a Commodore 64 in 1986. I had used Word Perfect a few times to type up an essay, but mostly I did all 
my work on a Smith Corona electric type writer." When asked about his computer use in the work place in the 1990s James said, "I worked for an NGO, the budgets were tight, all the paper work, reports and the like were done by hand - good old paper and pen." Later, James travelled to Korea to teach English and there too, technology created problems for him:

All the keyboards were in Korean; it was a nightmare. I avoided computers as much as I could. But as time went on it was more difficult to do so, the Korean government embraced technology. We had computer labs, no classroom computers; I used e-mail, but at the time I could avoid using computers in my teaching and in my classroom, it wasn't that hard.

James' expression of now having to "start from the bottom up" and feeling like he had to play "catch up" in his proficiency initially betrayed an understanding of the utilitarian benefits of technology (Miller, 2007). Computer applications can make presentations more effective; word processing tidies up essays. But James also had very clear ideas about what constitutes "text" and multimedia. Digital texts and an expanded notion of text that includes multimedia digital genres was, as James put it, "quite shocking" and he admitted "it wouldn't have occurred to me." Miller (2007) says this expansion of the boundaries of what is traditionally considered text also causes anxiety in that teachers' hard-won knowledge about print-text is seemingly antiquated. Among traditionally prepared English majors now taking English methods courses, there is a concern about what "counts as English" (Miller, 2007, p. 69; Swenson, et al., 2006). The notion of the literary canon and the centrality of print-based text was something with which James struggled. Although he shared his love of film and the memories of the rare times when film adaptations made their way into his undergraduate English courses, James had great reservations about the role of technology in the classroom. "I had the opportunity to do some teaching via Skype once, but it wasn't for me. I don't know - it is so impersonal, the relation is missing. It should be more Socratic, school should be for something else more experiential." James' identity as a teacher is deeply formed by traditional, transmissive teaching practices. The idea of de-centering authority and expanding the notion of text initially proved to be shocking and anxiety producing.

James' partner, Mijung (pseudonym), who was present for the interview, corroborated James' discomfort and his anxiety. She reported James would confide in her on their evening walks that he had no idea how he would manage to create a multimodal digital text. Ironically, it was just the aspect of technology that James disparaged, the lack of an experiential relation, that would be the element central to James' eventual success. James was introduced to Jimmy (pseudonym), a Fine Arts graduate whose area of expertise was film-making and digital media. Jimmy was acting as a technical support person for the project and spent time visiting the class and sharing his projects with students. Jimmy spent time with James discussing James' ideas and what media would be best suited to his purposes. Jimmy also introduced the class to the world of DIY (do it yourself) media. DIY media is characterized by people being able to produce their "own media - radio-like podcasts, re-mixed music, animated video etc. - by making use of software, hardware and 'insider' skills previously only in the domain of highly trained experts" (Lankshear \& Knobel, 2010, p. 10). Axel Bruns (2008) posits that conventional 
distinctions between producers and consumers are blurring within on-line, networked communities and he argues for a new hybrid term: the "produser" (p. 266). That is, produsers "use" rather than consumer artifacts, knowledge, information, content and other resources. What is prodused is always available to others and open to revision and re-working. James embarked upon the creation of a digital comic interface in the style of a graphic novel using scenes from the movie Reservoir Dogs (Dir. Tarantino, 1992). His purpose was to explain through a digital text the ethical dilemma of banning books. James described the process as

...stepping through the door, I had no idea that my love of movies and comics could come together with this mechanized thing to create something totally new, to say and do something that has never been said or done quite that way before. Jimmy was a great help, but really he was there to point me in the right direction, the on-line groups, and the resources available, I had no idea. I was reading an article about banned books and watching Reservoir Dogs at the same time and it occurred to me that the two may be compatible.

James' digital media text (see Figure 1) and his description of the experience of support are what scholars like Gee (2003), Jenkins (2006), Prensky (2010), and Brown and Adler (2008), among others, have discussed regarding how on-line resources and popular culture affinities have converged in ways to enable modes of learning very different from the predominantly "push" approach of conventional schooling. Brown and Adler (2008) discuss this convergence in relation to how new technologies have helped contribute to the development of a "demand" or "pull" approach to learning.

From a social learning perspective the emphasis is more on how we learn than what we learn. Social learning also puts the emphasis on "learning to be" (Brown \& Adler, 2008) while mastery involves learning subject matter. Also "learning to be" is about becoming a full participant in the field. James admits:

I understand now that many of the techniques are about acquiring a skill and like anything else it requires practice... learning to create multimedia texts is very much like learning a new language and for someone who is trying to learn Korean, I know that is best done through immersing yourself in the communities where the language is spoken-it's the same as on-line.

James' comic represents a tentative, exploratory step toward creating images and text as an aesthetic, self-originated, self-sponsored activity. Digital technologies have increasing capacity for individuals to adapt the tools for their own information and communication purposes. Students have the capability to apply literacy skills to real world problems and knowledge-building. They are able to exercise creativity, and work for social justice. In this case raise awareness of the issue of censorship through a satirical appropriation of a popular culture text and pursue a personal passion. 

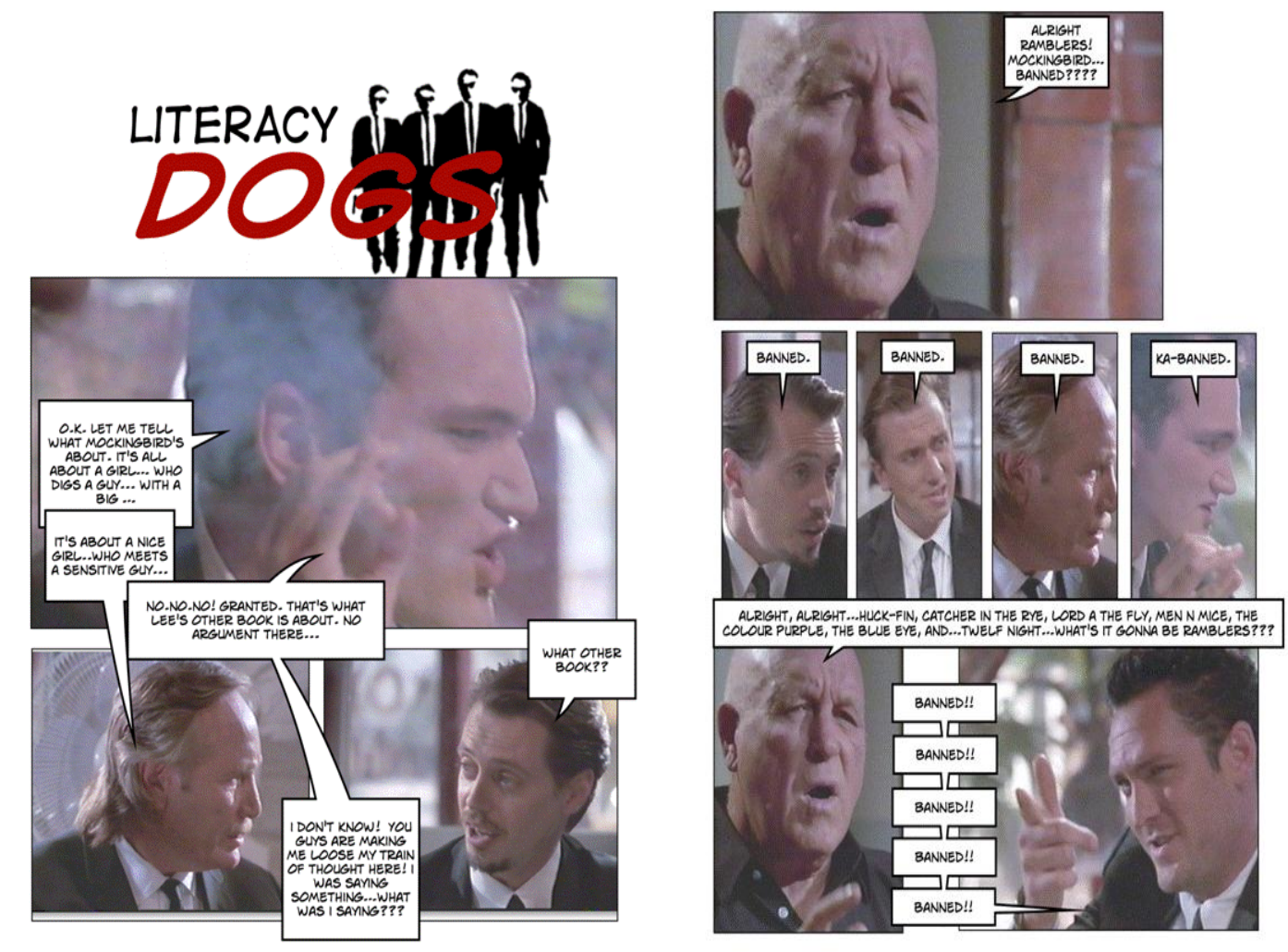

Figure 1.

\section{Anna}

Research suggests the barriers and anxieties experienced by James, a more mature student than is typical in teacher education programs, are not uncommon, nor are those barriers and anxieties uncommon to many experienced classroom teachers (Miller, 2007). However, generalizations are to be avoided. Anna, an enthusiastic 23-year-old, came to the teacher education program from a Bachelor of Arts degree majoring in English and drama. She said, "I have been drawing with Photoshop since I was young, but I haven't done it for years. I had lost my connection with digital art and I used this project to reconnect with an old passion." Anna fully embraces the expanded notion of text to include multimedia digital texts. Her undergraduate English degree included "a class where we studied paintings and poetry together (from the same period), in another class we studied film and in a Gothic literature class we studied film and comic books." For her digital media project, Anna chose to respond to a poem, Valentine by Carol Ann Duffy. Below is an excerpt from the poem: 
Not a red rose or a satin heart.

I give you an onion.

It is a moon wrapped in brown paper.

It promises light

like the careful undressing of love.

Here.

It will blind you with tears

like a lover.

It will make your reflection

a wobbling photo of grief. ..

Anna's response to the poem was a digitally constructed visual representation using Photoshop which she posted on DeviantArt.com. The site is described as, "a community destination... a platform that allows emerging and established artists to exhibit, promote and share their works within a peer community dedicated to the arts... (aboutDeviantArt.com). An analysis of the sophisticated level of response required to create the digital media text goes beyond the scope of this paper. But it should be said she was able to read and interpret the poem for personal connections and then combine strategies, resources and technologies to formulate a response. Choosing the form she did allowed her to explore, clarify, and reflect on her thoughts and prior learning while using her imagination. Creating the text while drawing on a global community of like-minded individuals to offer feedback in a highly generative, participatory environment provides a learning experience that embodies the pull approach to learning rather than the traditional "push" approach. Anna's capabilities and engagement are fostered and develop in such a participatory community as she is helped to learn and also to innovate, by pursuing paths of learning tailored specifically to her needs.

Scholar Henry Jenkins (2006) believes the new media literacies should be seen as social skills, as ways of interacting within a larger community, and not simply an individualized skill to be used for personal expression. Anna's experience with creating her digital media response to a print-based poem illustrates this. Jenkins (2006) writes,

The social production of meaning is more than individual interpretation multiplied; it represents a qualitative difference in the ways we make sense of cultural experience, and in that sense, it represents a profound change in how we understand literacy. In such a world, youth need skills for working within social networks, for pooling knowledge within a collective intelligence, for negotiating across cultural differences that shape the governing assumptions in different communities, and for reconciling conflicting bits of data to form a coherent picture of the world around them. (p. 98) 


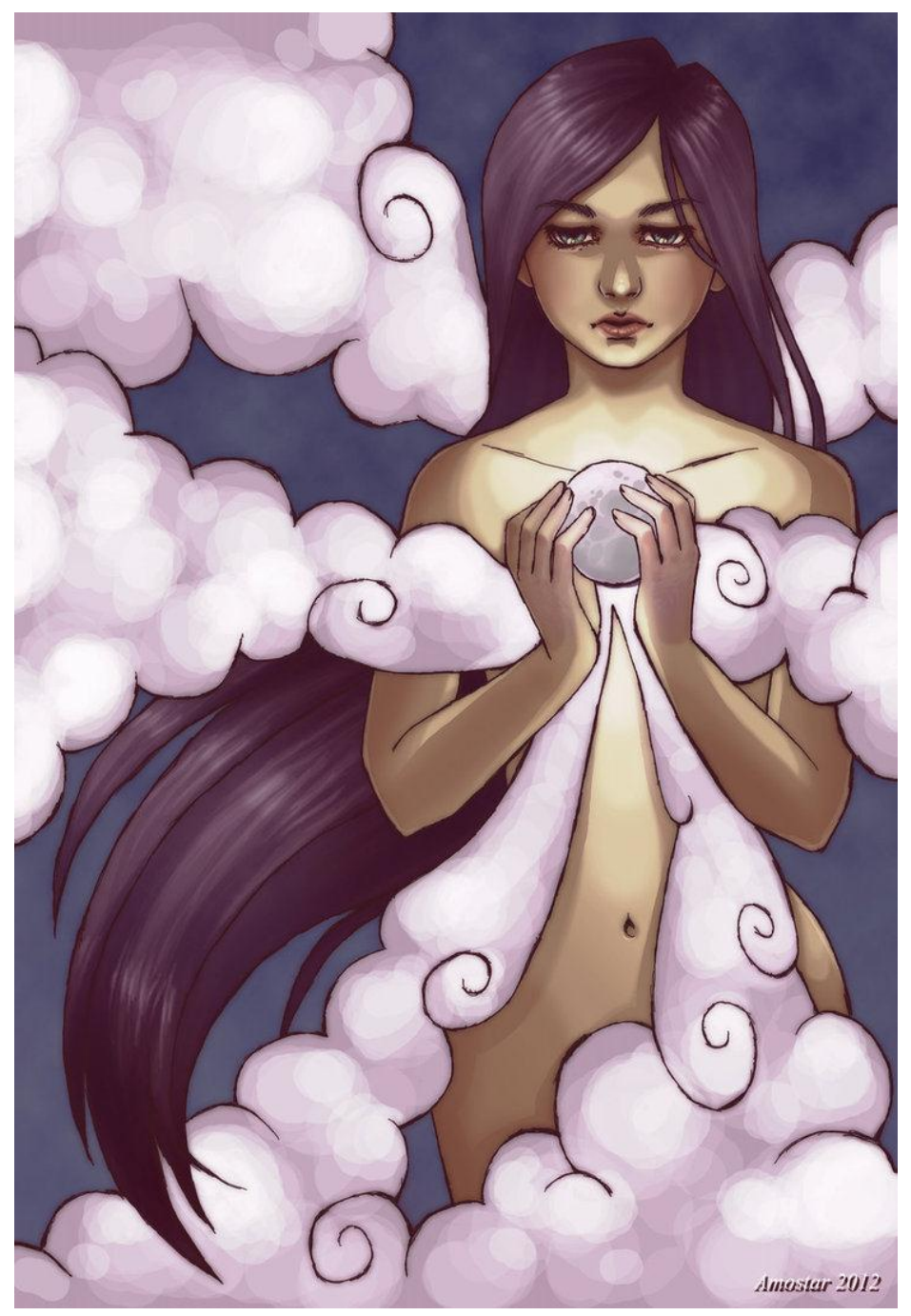

Figure 2.

In Anna's online journaling she reflected on her involvement with the website DeviantArt. In essence, Anna describes the concept of "social learning" as developed by Brown and Adler (2008) as the type of learning associated with innovation and creativity among participants in affinity spaces. People learn in the company of others within "grounded contexts of practice (Lankshear \& Knobel, 2011). Anna wrote:

I joined DeviantArt nine years ago on June 26th, 2003, so I would have been 12 years old. That was actually the year my family got a computer. Since joining I have posted many pictures and taken many off of my account, but there are currently 373 "deviations" (artworks) still in my gallery. I have received 4242 comments, 19182 page views and 153 people watch my gallery. This means when I upload a picture, those people are informed. 
Anna's participation in the affinity space represented by DeviantArt.com demonstrates the sophisticated participatory medium, the dynamic ecological system that the web has become as it provides rich opportunities for sharing and supports 'multiple modes of learning" (Brown \& Adler, 2008, p. 18). Anna, in essence, brought her on-line social network into the project and all of those people had access to what Anna was doing in the research project. In describing what happens on deviantart.com Anna said in an interview:

The environment is very supportive. The majority of comments are pleasant unless you post something controversial, and the community looks forward to future posts. When I upload something to the website I always receive a "welcome back" or "nice to see you" from other members. As well, even the more popular artists will generally answer questions you post on their art. For example, if someone creates an image and I want to know how they added text to it, they will either explain their method or send a link to a tutorial. Everyone always helps when asked. As well, DeviantArt now has its own chat room section where artists can talk about just about anything. The rooms are sectioned by topics, such as photography or a region. Individuals can even create their own rooms. Contests are held in many of these chat rooms. Others are for sharing your art, and some are just for moral support. If you are having a bad day and want to be cheered up, a quick stroll to the chat rooms will brighten your day.

Anna is describing a community of practice that is supportive, that provides mentorship, scaffolding and it would seem, camaraderie. However, it must be noted that this is not always the case and such support is not everyone's experience. Immersing pre-service teachers in the practice of digital text creation facilitated through on-line communities and affinity spaces will promote awareness of what is available to students by learning through, and with, the potential of on-line communities. Pre-service teachers are challenged to find ways to integrate these new knowledge cultures into our schools, not only through group work, but also through long-distance collaborations across different learning communities. This will be crucial if students are to discover what it is like to contribute their own expertise to a process that involves many intelligences.

Anna's description speaks to the tone or the climate of the on-line learning space for her. Critiques of online learning have called into question the quality of the learning experience in such virtual spaces because the spaces lack the immediate and direct, physical contact with an - other (Dreyfus, 2008). However, Friesen (2011) in the book The Place of the Classroom and the Space of the Screen: Relational Pedagogy and Internet Technology refutes such critiques in a manner that supports Anna's experience within the DeviantArt affinity space. Relying on phenomenological analysis of scholars like Levinas and Logstrup, Friesen believes the preclusion of direct contact in on-line discussion does not negate the existence of responsive, deeply meaningful encounters between the "self" and the "other" that happen in on-line forums. Friesen (2011) writes:

Although they are different experiential qualities, on-line encounters are not somehow devoid of authenticity, risk or the potential for care... the fundamental 
characteristics of relational, experiential pedagogy can be readily identified as being present in on-line discussion (p. 155).

Friesen's research demonstrates "tone," "climate" or "atmosphere" that is positive or supportive and that is conducive to participation and engagement (2011, p. 156) can be cultivated in an on-line learning community.

\section{Kyle}

The most technically sophisticated digital media text created for the research project was a stop motion, white board illustrated, presentation of an original poem combining narration and music. Kyle consented to have his identity revealed in the interest of allowing his digital text to be made available through YouTube.

http://www.youtube.com/watch?v=squrP-i-8c8

Kyle, a 23-year-old post-baccalaureate student admits:

Before coming to the B.Ed program I had some experience using technology and editing software. I have used Audacity and GarageBand, in high school I hosted a web radio station... I have worked briefly with Photoshop, MS Paint... but I have never used video editing software before this assignment.

Kyle indicated his initial emotion on hearing about the multimedia project was “...excitement. My head started swimming with ideas for possible projects I could create." Many pre-service teachers like Kyle have engaged in literacy practices predominately outside of school and point to a disconnect between the literacies valued in school and the digital practices in which they are immersed and that have life validity (Mills, 2010) for them. Kyle admits that his previous digital projects were never considered "texts." He said, "I did them on my own time out of my interest in technology. I didn't consider them texts, but a separate entity." Kyle was most excited that, for the first time in his life, the time spent on this digital project would not be replacing time spent on traditional, print-based "writing" demanded by school. Marc Prensky (2010) makes just this point when he posits that real literacy experience and New Literacies are being learned in the afterschool space, and not in the traditional classroom.

... the place where the biggest educational changes have come is not in our schools; it is everywhere else but our schools. The same young people we see bored and resistant in our schools are often hard at work learning afterschool (a term I use to encompass informal learning through peers, the Internet, YouTube, games, cell phones...It is the afterschool world, rather than in schools, that many of our kids are teaching themselves and each other all kinds of important and truly useful things about their real present and future. (Prensky, 2010, p. 2)

In our conversation Kyle indicated this type of learning, as described by Prensky, was evident in his design and creation of a stop motion video project unlike anything he had 
ever attempted before. "I learned by playing with the software ... I would look up tutorials on the internet and YouTube videos ... asking my friends ... trial and error is most time consuming aspect ... there is so much that goes into a digital project that the learning never stops."

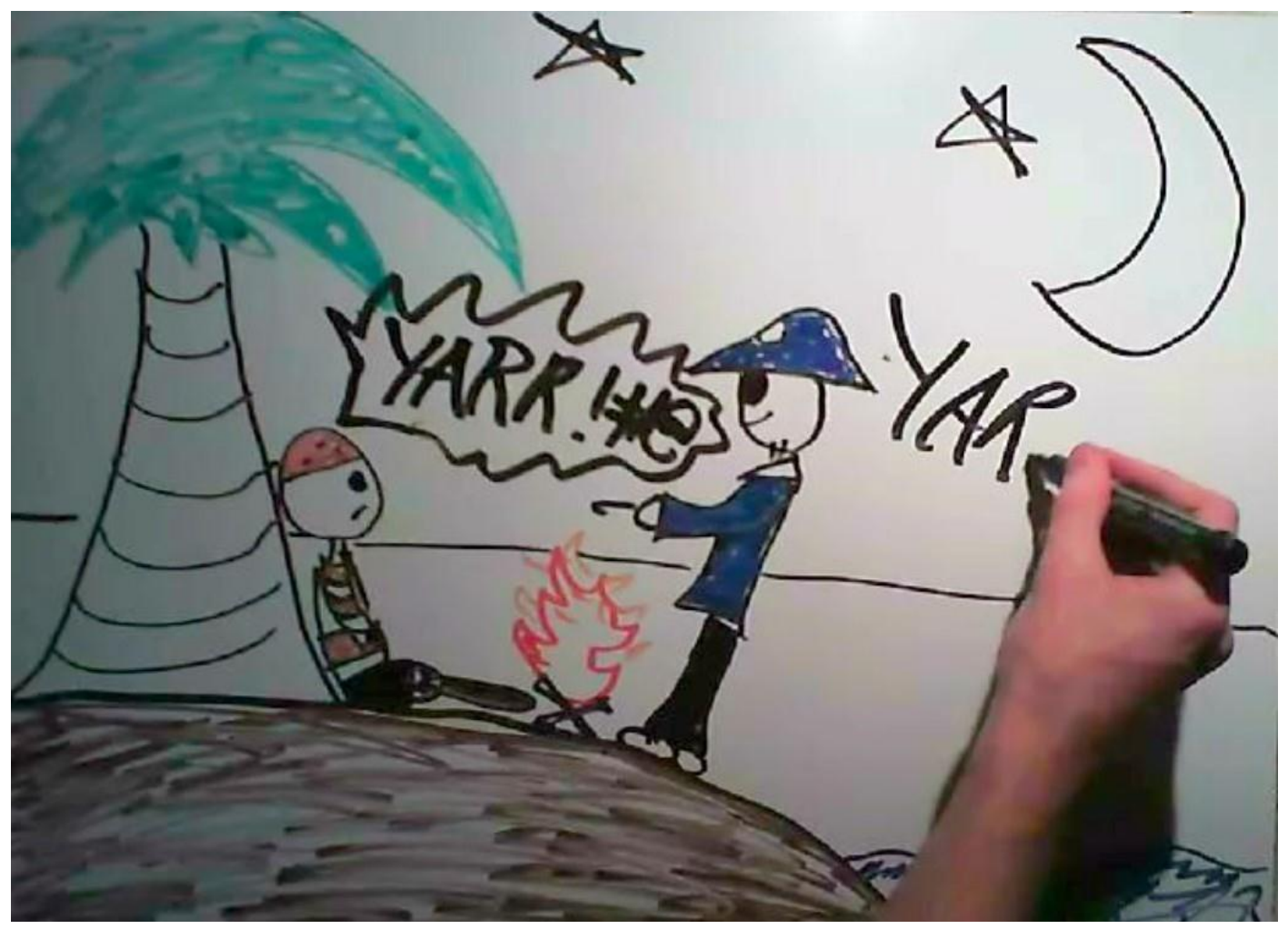

Figure 3.

It is in this sense that Kyle's experience illustrates what is 'new' in New Literacies. Lankshear and Knobel (2011) explicate the "new" in New Literacies in an ontological sense. First, the "new" in New Literacies is concerned with a fresh approach to thinking about literacy as a social phenomenon. As many of the students in this study demonstrated New Literacies are often more 'participatory', more 'collaborative', and more 'distributed'; less 'published', less 'individuated', and less 'author-centric' than conventional literacies. They involve different kinds of social and cultural relations..." (Lankshear \& Knobel, 2011, p. 29). Secondly, the new has to do with the rise of digital technologies and the emergence of "post typographic forms" (Lankshear \& Knobel, 2011, p , 28) of text and text production. Social practices in the main areas of life in contemporary society are changing with evolving ways of producing, distributing, exchanging and receiving texts electronically. These changes, according to Lankshear and Knobel (2011) include, "the production and exchange of multimodal forms of texts that can arrive via digital code as sound text, images, video, animations and any combination of these" (p. 28).

The affinity spaces and emerging participatory culture represent sociocultural practices in literacy learning that stand to re-shape how literacy educators perceive their 
role and their understanding of appropriate instructional practices in meeting learning outcomes associated with New Literacies. More than ever, new directions in sociocultural studies in language and learning challenge the assumptions that learning involves transmitting abstract, decontextualized formal concepts; that knowledge can be understood as "theoretically independent of the situations in which it is learned and used; that the context and activity in which learning occurs can be understood as 'ancillary to learning' rather than inseparable from and integral to what is learned" (Brown et al, 1989, in Lankshear \& Knobel, 2011, p. 211). This point also echoes Brooke's (2009) ecologies of practice in that the text creation activities take place within evolving systems shaped by individual users, technologies and the intersections of dynamic contexts. Pre-service English teachers require opportunities to engage in learning grounded in authentic activity, in physical and social contexts and situations. Experiencing firsthand the creation of digital multimodal texts through engagement in affinity spaces will allow preservice teachers to do otherwise than to fall back on de-contextualized, traditional learning separated out of situated everyday engagements thereby defeating the goal of literacy education.

\section{Conclusion}

For the purposes of this paper, three student experiences were drawn from a class of twelve pre-service English education students participating in the project. Each example represents a unique experience from which we may draw insight and direction as English educators. Despite the ever present barriers (resources, time, restrictive curricula/assessment) to integrating afterschool (Prensky, 2010) literacy practices into traditional schools and to ensure what we are teaching has the important element of life validity (Mills, 2010) while reflecting the evolving sociocultural literacy practices of contemporary society, English educators must provide authentic, engaging opportunities for pre-service teachers to learn about and through multimedia, multimodal digital technologies. Digital literacy practices should be seen within larger systems of activity and expanded literacy ecologies that recognize and enable people to build and participate in literacy practices that involve different kinds of values, sensibilities, norms and procedures from those that characterize conventional literacies. Ecological thinking assists educators in understanding the intertwined elements of new media that exist over vast distances of space and time. In the dynamism of an ecological system, it is important to recognize practices that may be unintended or unanticipated. Students utilize and repurpose interfaces growing their ecology of practice through interpersonal relationships and participatory communities that reach out globally.

Text creation is occurring in digital spaces in ways that require us to rethink our notions of how we teach. New Literacies, in many ways, represent hybrid systems and taking up an ecological perspective will inform our ability to read, write, design and produce new media and facilitate its production with our students. It is these values and pedagogies of collaboration and participation, harnessing collective intelligence, building relationships, de-centering authorship, that are to be regarded not in opposition to traditional literacies, but as exciting spaces and contexts for coalescing the old and new to motivate, engage and allow students to fully participate in the literacy practices that currently shape who they are, and how they are in the world. 


\section{References}

Ambert, A., Adler, P.A., Adler, P., \& Detzner, D.F. (1995). Understanding and evaluating qualitative research. Journal of Marriage and the Family, 57, 879893.

Atwell, N. (1993). In the middle: New understandings about writing, reading and learning $\left(2^{\text {nd }}\right.$ ed.). Toronto, ON: Irwin Publishing.

Bainbridge, J., Heydon, R., \& Malicky, G. (2009). Constructing meaning: Balancing elementary language arts. Toronto, ON: Nelson.

Barrell, B., \& Hammett, R. (2000). Advocating change: Contemporary issues in subject English. Toronto: Irwin Publishing.

Barrell, B., \& Hammett, R. (2002). Digital expressions: Media literacy and English language arts. Calgary, AB: Detselig Enterprises.

Barrell, B., Hammett, R. Mayher, J., \& Pradl, G. (2004). Teaching English today: Advocating change in the secondary curriculum. New York, NY: Teachers College Press.

Brooke, C. (2009). Lingua fracta: Towards a rhetoric of new media. New Jersey: Hampton Press.

Brown, J., \& Adler, R. (2008). Minds on fire: Open education 2.0. Educause Review, January/February, 17-32.

Buck, A. (2012). Examining digital literacy practices on social network sites. Research in the Teaching of English, 47 (1), 9-38.

Burn, A., and Nixon, H. (2005). English and the visual: From montage to manga. English Teaching: Theory and Practice, 4 (1), 1-5.

Bruns, A. (2008). Blogs, Wikipedia, Second Life and beyond. From production to produsage. NewYork, NY: Peter Lang

Calkins, L. (1994). The art of teaching writing (2nd ed.). Portsmouth, NH: Heinemann.

Cervetti, G., Damico, J., \& Pearson, D. (2006). Multiple literacies, new literacies and teacher education. Theory into Practice, 45 (4), 378-386.

Cooper, M. (1986). The ecology of writing. College English, 48 (4), 364-375.

Cope, B., Kalantzis, M. (Eds.).(2000). Multiliteracies: Literacy learning and the design of social futures. New York: Routledge.

Cuban, L. (2001). Oversold and underused: Computers in the classroom. Cambridge, MA: Harvard University Press.

Dobson, T., \& Willinsky, J. (2009). Digital literacy. In D. Olson \& N. Torrance (Eds.), The Cambridge handbook of literacy (pp. 286 - 312). New York, NY: Cambridge University Press.

Doering, A., Beach, R., \& O’Brien, D. (2007). Infusing multimodal tools and digital literacies into an English education program. English Education, 40 (1), 41-60.

Dreyfus, H. (2008). On the internet ( $2^{\text {nd }}$ ed.). New York: Routledge.

Friesen, N. (2011). The place of the classroom and the space of the screen: Relational pedagogy and internet technology. New York: Peter Lang.

Gee, J. (1990). Social linguistics and literacies: Ideology in discourses. London: Falmer.

Gee, J. (2003). What video games have to teach us about learning and literacy. New York, NY: Palgrave-MacMillan. 
Gee, J. (2004). Situated learning and language: A critique of traditional schooling. New York: Routledge.

Grabhill, J., \& Hicks, T. (2005). Multiliteracies meet methods: The case for digital writing in English education. English Education, 37(4), 301 -311.

Graves, D. (1983). Writing: Teachers and children at work. Portsmouth, NH: Heineman. Greenleaf, C. (1992). Technological indeterminacy: The role of classroom practices in shaping computer use (Technical Report No. 58). Berkeley, CA: Center for the Study of Writing.

Howard, P. (1987). Students' Use of Television in Two Newfoundland High Schools. (Unpublished field study). Memorial University of Newfoundland.

Jenkins, H. (2006). Confronting the challenges of participatory culture: Media education in the $21^{\text {st }}$ century. Retrieved from http://www.digitallearning.macfound.org/ .

Kittle, P. (2008). Write beside them: Risk, voice and clarity in high school writing. Portsmouth, NH: Heineman.

Knobel, M., \& Lankshear, C. (2007). A new literacies sampler. New York, NY: Peter Lang.

Kress, G. (2003). Literacy in the new media age. London, UK: Routledge.

LaMonde, A., \& Rogers, T. (2007). Infusing arts/multimedia into secondary pre-service course on learning and literacy across disciplines as imaginative and critical practice. Language \& Literacy: A Canadian e-Journal 9 (2). Retrieved from: http://www.langandlit.ualberta.ca/archivesDate.html.

Lankshear, C. (1997). Changing literacies. Buckingham and Philadelphia: Open University Press.

Lankshear, C., \& Knobel. (2010). DIY media: Contextual background and some contemporary themes. In M. Knobel \& C. Lankshear.(Eds.). DIY media: Creating, sharing and learning with new technologies (pp. 1 -26). New York, NY: Peter Lang.

Lankshear, C., \& Knobel, M. (2011). New literacies: Everyday practices and social learning $\left(3^{\text {rd }}\right.$ ed.). New York: Open University Press.

Miller, S. (2007). English teacher learning for new times: Digital video composing as multimodal literacy practice. English Education, 40 (1), 61-68.

Mills, K. (2010). A review of the digital turn in the new literacy studies: Review of Education Research, 80 (2), 246-271.

Murray, D. (1982). Learning by teaching. Portsmouth, NH: Boynton Cook.

Murray, D. (1993). A writer teaches writing (2 $2^{\text {nd }}$ ed.). Boston, MA: Houghton Mifflin.

Myers, J. (2006). Literacy practices and digital literacies: A commentary on Swenson, Rozema, Young, McGrail, and Whitin. Contemporary Issues in Technology and Teacher Education, 6(1).Retrieved from http://www.citejournal.org/vol6/iss1/languagearts/article5.cfm

National Council of Teachers of English. (2005). NCTE position statement on multimodal literacies.Retrieved from http://www.ncte.org/positions/statements/multimodalliteracies

Owston, R. (1992). The effects of word processing on students' writing quality and revision strategies. Research in the Teaching of English, 26 (3). 249-276 
Porter, J. (2007). Forward. In H. McKee \& D. DeVoss (Eds.), Digital writing research: Technologies, methodologies and ethical issues (pp. ix - xix). New York, NY: Hampton Press.

Pahl, K., \& Rowsell, J. (2005). Literacy and education: Understanding the new literacy studies in the classroom. London, UK: Paul Chapman.

Prensky, M. (2010). Teaching digital natives: Partnering for real change. Thousand Oaks, CA: Corwin.

Robertson, L., Hughes, J., \& Smith, S. (2012). Thanks for the assignment! Digital stories as a form of reflective practice. Language and literacy, 14 (1). Retrieved from ejournals.library.ualberta.ca/index.php/article/view/1678

Romano, T. (1987). Clearing the way: Working with teenage writers. Portsmouth, NH: Heineman.

Rosen, L., Chang, J., Erwin, L., Carrier, M., \& Cheever, N. (2010). The relationship between "textisms" and formal and informal writing among young adults. Communication Research, 37(3), 420 -440.

Soven, M. (1999). Teaching writing in middle and secondary school: Theory, research and practice. Boston, MA: Allyn and Bacon.

Swenson, J., Rozema, R., Young, C., McGrail, E., \& Whitin, P. (2005). Beliefs about technology and the preparation of English teachers: Beginning the conversation. Contemporary Issues in Technology and Teacher education, 5 (3/4), 351-369.

van Manen, M. (1997). Researching lived experience: Human science for an action sensitive pedagogy. London, ON: Althouse Press.

Vygotsky, L. (1986). Thought and language. Boston, MA: MIT.

Author Biography

Dr. Patrick Howard is an Associate Professor of Education at Cape Breton University. His research interests are in teacher education, digital media and participatory cultures, and the intersections between literacy learning and education for sustainability.

Acknowledgement: This research was supported by the Social Sciences and Humanities Research Council through an Insight Development Grant No. 430-2011-0002 